\title{
Hope Beyond Disappointment: A Reparative Reading of Charlson Ong's Of That Other Country We Now Speak
}

\author{
Miao Chi \\ University of Macau. ORCID ID: oooo-ooo2-0511-6235.Email: yb97721@um.edu.mo
}

\begin{abstract}
The practice of depicting ancestral homeland as a mythical and ideal place where the diasporic subjects will eventually return has been problematized and contested in diasporic studies. Seemingly pioneering, such an approach perpetuates a paranoid reading of homecoming and return as an experience of disappointment, confusion, and conflict, which in turn bolsters the sense of alienation of diasporic subjects. Despite the contentions, the idea of home still has its hold on diasporic subjects. Considering the complexity and significance of the notion of home in diasporic studies, I argue that the homecoming journey could also create positive impacts on healing the wound inflicted by diasporic experience. Employing Eve Sedgwick's theory of reparative reading, which empowers generative mode of analysis that explores alternatives through textual critique, I offer a reparative reading of the title story in Of that Other Country We Now Speak and Other Stories, a recent collection of short stories by the award-winning Chinese Filipino writer Charlson Ong. I focus especially on the experience of the protagonist Jeffrey and examine how his adversity is complicated by the diasporic experience, the symbolic meaning of his homecoming trip as well as how his narration of a mythological story parallels with and symbolizes his endeavors to heal the misfortune. In doing so, this essay hopes to provide an alternative perspective on the often negativelyperceived homecoming experience.
\end{abstract}

Keywords: diaspora; homecoming; reparative reading; Chinese Filipino; Charlson Ong

\section{Introduction}

In diasporic studies, the idea of home has been the focus of many contentions. William Safran (1991) proposes six key characteristics of diaspora, one of which is that diasporic subjects

"regard their ancestral homeland as their true, ideal home and as the place to which they or their descendants would (or should) eventually return" (p. 83).

However, Safran's model was criticized for privileging the homeland as a source of orientation. Some (Anthias, 1998; Brah, 1996; Clifford, 1994) aver that the centrality of home should be deemphasized since some diasporic subjects do not have a strong desire for an eventual return. Such a refutation is right in rectifying the overemphasis laid on homeland. Yet it somehow fosters a paranoid reading of the return experience of diasporic subjects. Much sociological research and literary works tend to accentuate the negative feelings diasporic subjects have during and after their homecoming experience. Usually, the expectations of diasporic people conflict with reality. They experience the cultural conflict between their hostland and the ancestral homeland. All the negative experiences bolster their sense of disappointment and alienation.

However, considering the multi-faceted nature of homeland, both an overemphasis and underemphasis of homeland can lead to lopsided understanding. Hence, Cohen (2008) suggests

\footnotetext{
(c) AesthetixMS 2020. This Open Access article is published under a Creative Commons Attribution Non-Commercial 4.o International License (http://creativecommons.org/licenses/by-nc/4.o/), which permits non-commercial re-use, distribution, and reproduction in any medium, provided the original work is properly cited. For citation use the DOI. For commercial re-use, please contact editor@rupkatha.com.
} 
that home/homeland should be perceived as "a fluid, vibrant and frequently changing set of cultural interactions" (p.123). Following Cohen's vein, I propose that homecoming/return experience of diasporic subjects can also be read from alternative perspectives. I argue that the homecoming journey could create positive impacts on healing the wound inflicted by diasporic experience. Employing Eve Sedgwick's theory of reparative reading, which empowers generative mode of analysis that explores alternatives through textual critique, I offer a reparative reading of the title story in Of that Other Country We Now Speak and Other Stories, a recent collection of short stories by the award-winning Chinese Filipino writer Charlson Ong. The story is centered around Jeffrey Lim, a Chinese Filipino who experiences a homecoming journey of exploring his clan's mythical tale. In my reading, I focus on Jeffrey's homecoming experience and examine how his adversity is complicated by the diasporic experience, the symbolic meaning of his homecoming trip as well as how his narration of a mythological story parallels with and symbolizes his endeavors to heal the misfortune. In doing so, this essay hopes to provide an alternative understanding of the homecoming experience.

\section{Paranoid Reading and Reparative Reading}

In her pioneering essay, Paranoid Reading and Reparative Reading; or You're So Paranoid, You Probably Think This Introduction Is about You, Sedgwick (1997) points out that a common feature of criticism is a "stance of suspicion and paranoid" (p.3). In criticism, the application of "hermeneutics" has almost become a "mandatory injunction rather than a possibility among other possibilities" (p.5). The centrality of suspicion in critical practice "has involved a concomitant privileging of the concept of paranoia" (p.5).

To make it specific, Sedgwick (1997) lists several characteristics of paranoia. Paranoia is anticipatory as it "requires that bad news be always already known" (p.10). Also, paranoia is a "strong theory of negative affect" (p.15). It is capable to encompass a wide spectrum of phenomena. As a strong theory, paranoia is hegemonic since it can lead to elimination of alternative interpretations. If such an approach persists unquestioned, it will impoverish "literarycritical perspectives and skills" and diminish the "ability to respond to environmental (for instance, political) change" (p.21). To address this problem, Sedgwick proposes reparative orientation, which can offer "specific, divergent dimensions" and "alternative approaches" (p.23). Reading from reparative position is to

"surrender the knowing, anxious paranoid determination that no horror, however apparently unthinkable, shall ever come to the reader as new" (p.24).

Compared with paranoia position, reparative position "picks up the fragments to construct a sustainable life" (Hanson, 2011, p. 102). It is "on the side of multiplicity, surprise, rich divergence, consolation, creativity, and love” (Love, 2010, p. 237).

In literary critique, paranoid orientation often "encourages hostile relationship to cultural texts", which can lead to "a practice that involves categorizing texts as either radical or reactionary" (De Chavez \& Lin, 2020, p. 1). Diasporic studies also share such currency. In diasporic studies, paranoid reading seems to be pervading, especially the negative connotation of diaspora with alienation, estrangement, and displacement as well as the counter-narrative of diaspora as a subversive force. Yet, considering its complicated nature, a reparative reading can provide a supplementary perspective for understanding diaspora.

\section{A Reparative Interpretation of the Story}


While previous sections offer a general introduction and the theory, in this section, I aim to conduct a reparative reading of the story. And I divide Jeffrey's experience into three periods: the pre-homecoming period, homecoming period, and post-homecoming period.

In the pre-homecoming period, the tale was narrated for the first time. Jeffrey was trying to tell the tale he heard from his grandmother to his wife. Jeffrey mentioned that it was

"the curse of the poor poet that has plagued our family ever since, that followed us across many rivers and oceans" (Ong, 2016, p.1).

Yet, who was the poet, what was the dragon, and what was the curse were unknown. Much information was unknown.

As Jeffrey narrated the tale, he disclosed one motivation for homecoming. When Jeffrey was a child, his grandmother told him a story about a woman who hid the moon in an earthen jar. His grandmother had asked Jeffrey to "promise to return to her village one day and recover the earthen jar where she had hidden the moon" (Ong, 2016, p. 2). So, a part of Jeffrey's motivation is to keep the promise he made to his grandmother. Unlike his grandmother who had a strong desire to return to the homeland in China, Jeffrey did not yearn for a homecoming trip, which would be perceived as a demonstration of diasporic subjects' loss of interest in ancestral homeland by paranoid reading. However, when Jeffrey knew that his daughter was affected by autism, he did decide to return to the ancestral homeland. Hence, although not yearning for an eventual return, diasporic subjects may return to their ancestral homeland temporarily or regularly, a fact overlooked by paranoid reading. In regards to Katrina's autism, Dr. Blando consoled Jeffrey that Katrina's solitude was a gift which "could result in great achievement" (Ong, 2016, p.3) and suggested Jeffrey to give up looking for treatment. The bad news kept Jeffrey under pressure and anxiety. A paranoid reading would only highlight this negative feeling while discarding the fact that Jeffrey was not caught in desperation. The distinctiveness of Katrina, embodied through her mystical interpretation of three ways to go through the Great Wall, reminded Jeffrey of his aunt Lei Yun, who was also in solitude and also possessed a sort of genius. The affinity between Lei Yun and Katrina made Jeffrey think that Katrina's autism might be a curse that plagued his family. Hence, Jeffrey's attributing Katrina's autism to family curse is not a superstition caused by bewilderment. Rather, I propose that it is based on his logical analysis. Since Jeffrey knew that Lei Yun suffered from suspicion and detestation from others, he did not hope Katrina would go through similar sufferings. Therefore, Jeffrey decided to go back to the homeland to help Katrina get out of the curse. Hence, I read Jeffery's homecoming not as an action out of impulse or despair, but as a rational decision and an act of seeking salvation.

Although Jeffrey was determined to go back to the homeland, his homecoming experience was full of difficulties and surprises. His wife Agnes was the first person who objected to Jeffrey's decision. Since Agnes deemed the mystical tale a lie, she refused to accompany Jeffrey to go back to China. Agnes' misunderstanding and objection may be due to her identity and background. As a Filipino, Agnes could not understand the mystical tale and the so-called family curse. Apparently, there was a cultural conflict between Jeffrey and Agnes. Hence, Jeffrey's adversity was complicated by his diasporic identity. Unable to persuade Agnes, Jeffrey did not give up the idea. Since Jeffrey was not quite competent in Mandarin, he turned to his girlfriend Jin Lay, probably a native of Mainland China, for companionship. Through Jin Lay, Jeffrey might "find a way back" (Ong, 2016, p.2) to his grandmother's village. Before Jeffrey tried to persuade Jin Lay to accompany him, he narrated the story for the second time. It was a tale Jeffrey heard from his grandmother before his grandmother died in Hong Kong. Compared with the first version, the 
second version was more detailed. Why the river is cursed was disclosed. There was a poet who went after a widow every evening "by swimming in the river and reaching for the moon's image" (Ong, 2016, p.5). Fearing the ghost of her husband, the widow hid the moon in a jar. Unable to find the moon, the poet drowned in the river. Hence the river became cursed. However, this version still sounds like a simple story. Jin Lay preferred to believe in the doctor's judgment that Katrina was a genius than believing in the mystical tale. But Jin Lay finally accompanied Jeffrey to go to China. As Jin Lay had expected, Jeffrey's search of the earthen jar was not easy. When a taxi driver heard of the tale from Jeffrey, the driver said the river Jeffrey looked for was just an ordinary river. But the driver told Jeffrey another tale that many ancestral tablets were preserved in family shrines because Chairman Mao was saved by one of the tablets which were thrown into the river by the townspeople. Such an anecdote made Jeffrey decide to inquire about his family shrine. Hence, I read Jeffrey's decision not as an impulse, but as a calm action based on logical analysis.

Arriving at the ancestral hometown, Jeffrey did experience something unexpected. The old town had become modernized with "multistoried buildings" (Ong, 2016, p.7). A paranoid reading would view this as a conflict between reality and the imagined homeland. But I propose that the difference between reality and imagined homeland does not always generate conflict. Jeffrey did not care much about the modernization of his ancestral hometown. Instead, he was preoccupied with the search of the earthen jar. Jefferey continued his search by consulting the townspeople until one old man remembered Jeffrey's grandfather and grandmother. However, the old man doubted if Jeffrey could find anything in the river. Aware of the potential failure, Jeffrey still insisted on going to the river. It can be seen that Jeffrey is a person of perseverance. Besides, he successfully persuaded Jin Lay to bathe with him in that river in the night. However, Jin Lay became furious when Jeffrey begged Jin Lay to bear a child with him, which Jeffrey thought would be a way to save Katrina. Abandoned by Jin Lay, Jeffrey wandered lonely in the river, only to wake up in a hospital surrounded by a doctor and a policeman. The policeman seemed nice as he inquired whether Jeffrey remembered the face of any mob who might have assaulted him. However, when Jeffrey said he came looking for lost treasure, the policeman said the authorities wanted to return a dynasty vase to its owner if the owner paid a small fee. A paranoid reading would emphasize this indicates the corruption of local government as well as the conflict between reality and imagined homeland. However, I propose that we might turn our focus to Jeffrey's response. Instead of feeling annoyed or indignant about the corruption of the policeman, Jeffrey was unperturbed. He refused the offer of the policeman in a poised manner.

Seeking to eliminate surprise, a paranoid reading of the story would anticipate that Jeffrey would feel disappointed since Jeffrey did not find the earthen jar. However, as Sedgwick (1997) suggests, experiencing surprises can be realistic and necessary because there can be terrible surprises as well as good ones. If we shift our attention to Jeffrey's action after the homecoming trip, we may find good surprises. The scenario was quickly shifted from Jeffrey's conversation with the policeman to his telling the mystical tale to Katrina. It is the third time that the tale was narrated. Compared with the first two versions, more information was disclosed, including the identity of the dragon. Besides, there are other differences between the third version and previous versions. Firstly, instead of passively accepting the mystical tale, Jeffrey added his own imagination into it. Therefore, it was not only a heritage from his grandmother but also his own creation. Secondly, Jeffrey's tone was firm. Unlike previous narrations, this time Jeffrey told the tale in an imperative mood as he said "And so Katrina, listen now while I tell you this story that I bring you from my father's country” (Ong, 2016, p. 12). Given Katrina's special condition, she 
probably would not listen to Jeffrey's narration. Therefore, I read Jeffrey's telling the tale to Katrina as Jeffrey addressing himself. It is a tale that Jeffrey employed to encourage himself.

It can be seen that as Jeffrey's homecoming trip went on, the plot became clearer and Jeffrey became more assured. Hence, this trip is not only about finding the jar but also about retrieving faith and hope. In a sense, Jeffrey's homecoming trip is reparative because Jeffrey, while realizing the harsh reality, still clung to hope, "a crucial reparative energy" (Wiegman, 2014, p. 11). Jeffrey's experience demonstrates that the homecoming experience of diasporic subjects can induce creativeness to contest loss and displacement.

\section{Conclusion}

A native of magic and stark realism, Charlson Ong employs his imagination to detail how familial secrets significantly affect the present. Despite the magical elements, the story is rooted in reality and bears the truth of reality. As argued by Cohen (2008), diasporas are in a continuous process of formation. Therefore, the understanding of homeland and homecoming also assumes a dynamic characteristic. By focusing not on the exposure of the confusion and conflict but rather on the process of Jeffrey's endeavor to reconstruct a sustainable life, this essay gives recognition of the complexity and diversity of the homecoming experience of diasporic subjects. Through the homecoming journey, Jeffrey had an epiphany as the ancestral homeland was reinscribed with new meaning. A paranoid reading of homecoming can unveil the problem of placing homeland at the center of diasporic studies. However, as paranoia involves both assets and deficits (Sedgwick, 1997), it also can reduce the lived experience of diasporic subjects to a list of symptoms, and generate a stereotyped understanding of homecoming as an experience of confusion and conflict. Yet, as diaspora is often characterized by its hybridity of two cultures, i.e. the homeland and the hostland, looking for positive affect from both sites may be better than overvaluing one site over the other. Therefore, to avoid a paranoid reading, I propose that we shift our perception of homeland as a site of contestations to a view of homeland as a site for diasporic subjects to make use of. For diasporic subjects, homecoming can be a strategy of self-recovery as they re-imagine and re-locate themselves in the country of origin as well as their negotiations that shape new, adaptive selves in the countries of settlement. An emancipation from the constraints of paranoid reading of homeland and homecoming might help diasporic subjects better negotiate the different forces that inform and complicate their lived experiences and feelings.

\section{References}

Anthias, F. (1998). Evaluating 'diaspora': beyond ethnicity? Sociology, 32(3), 557-580.

Brah, A. (1996). Cartographies of diaspora: Contesting identities: Psychology Press.

Clifford, J. (1994). Diasporas. Cultural Anthropology, 9(3), 302-338.

Cohen, R. (2008). Global diasporas: An introduction: Routledge.

De Chavez, J., \& Lin, C. J. (2020). The Faithful Work of Drowning.": A Reparative Reading of Ocean Vuong's “Telemachus. The Explicator, 1-5.

Hanson, E. (2011). The future's eve: reparative reading after sedgwick. South Atlantic Quarterly, 110(1), 101119.

Love, H. (2010). Truth and consequences: On paranoid reading and reparative reading. Criticism, 52(2), 235241. 
Ong, C. (2016). Of that Other Country We Now Speak and Other Stories: University of the Philippines Press.

Safran, W. (1991). Diasporas in modern societies: Myths of homeland and return. Diaspora: A Journal of Transnational Studies, 1(1), 83-99.

Sedgwick, E. K. (1997). Paranoid reading and reparative reading, or, You're so paranoid, you probably think this introduction is about you. In E. K. Sedgwick (Ed.), Novel Gazing: Queer Readings in Fiction. Durham \& London: Duke University Press. 1-37.

Wiegman, R. (2014). The times we're in: Queer feminist criticism and the reparative 'turn'. Feminist Theory, $15(1), 4-25$.

Miao Chi is currently a PhD student in the University of Macau, majoring in Literary Studies (English). He is under the supervision of Professor Jeremy De Chavez. His research interest includes postcolonial literature, diasporic literature, literature and history. 